Original Article

\title{
Efficacy of acidified phytase supplemented cottonseed meal based diets on growth performance and proximate composition of Labeo rohita fingerlings
}

\author{
Eficácia de dietas à base de algodão com fitase acidificada suplementada no \\ desempenho do crescimento e na composição proximada de dedos de Labeo rohita
}

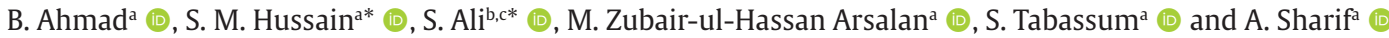 \\ ${ }^{a}$ Government College University Faisalabad, Department of Zoology, Fish Nutrition Lab, Faisalabad, Pakistan \\ ${ }^{\mathrm{b}}$ Government College University, Department of Environmental Sciences \& Engineering, Faisalabad, Pakistan \\ 'China Medical University, Department of Biological Sciences and Technology, Taichung, Taiwan
}

\begin{abstract}
The growth of aquaculture sector is strongly dependent upon the continuous supply of inexpensive fish feed with balanced nutritional profile. However, fish meal (FM) is unable to satisfy this demand due to its scarce supply and high cost. In order to test the potential of cottonseed meal (CSM) as a fish meal replacer, a feeding trial of 12 weeks was conducted to check growth performance and proximate composition of Labeo rohita fingerlings. The protein ration of the test feed was satisfied by replacing FM with CSM at 0,25, 50 and 75\%. Sixteen test diets viz., $\mathrm{TD}_{1}$ (control), $\mathrm{TD}_{2}, \mathrm{TD}_{3}, \mathrm{TD}_{4}, \mathrm{TD}_{5}, \mathrm{TD}_{6}, \mathrm{TD}_{7}, \mathrm{TD}_{8}, \mathrm{TD}_{9}, \mathrm{TD}_{10}, \mathrm{TD}_{11}, \mathrm{TD}_{12}, \mathrm{TD}_{13}, \mathrm{TD}_{14}, \mathrm{TD}_{15}$ and $\mathrm{TD}_{16}$ were supplemented with citric acid (CA; 0 and 2.5\%) and phytase (PHY; 0 and $750 \mathrm{FTU} / \mathrm{kg}$ ) in a completely randomized design with $3 \times 3$ factorial arrangement. The highest weight gain (11.03g), weight gain\% (249.21\%), specific growth rate (1.39) and best feed conversion ratio (1.20) were recorded by fish fed with $\mathrm{TD}_{12}$. Furthermore, the same level increased the crude protein (59.26\%) and fat (16.04\%) being significantly different $(\mathrm{p}<0.05)$ than that of control. Conclusively, the addition of acidified phytase (CA; $2.5 \%$, PHY; $750 \mathrm{FTU} / \mathrm{kg}$ ) in $\mathrm{TD}_{12}(\mathrm{CSM}=50 \%)$ led to the improved growth and proximate composition of $L$. rohita fingerlings.
\end{abstract}

Keywords: plant by-products, aquaculture, fish meal, cost-effective feed, body composition.

\section{Resumo}

O crescimento do setor de aquicultura é fortemente dependente do fornecimento contínuo de rações baratas para peixes com perfil nutricional equilibrado. Porém, a farinha de peixe (FM) não consegue atender a essa demanda devido à sua escassa oferta e alto custo. Com o objetivo de testar o potencial da farinha de semente de canola (MSC) como substituto da farinha de peixe, um ensaio alimentar de 12 semanas foi conduzido para verificar 0 desempenho de crescimento e a composição centesimal de alevinos de Labeo rohita. A ração de proteína da ração teste foi satisfeita substituindo FM por CSM em 0, 25, 50 e 75\%. Dezesseis dietas de teste, viz., TD1 (controle), TD2, TD3, TD4, TD5, TD6, TD7, TD8, TD9, TD10, TD11, TD12, TD13, TD14, TD15 e TD16 foram suplementadas com ácido cítrico (CA; 0 e 2,5\%) e fitase (PHY; 0 e 750 FTU / kg) em um delineamento inteiramente casualizado com arranjo fatorial $3 \times 3$. O maior ganho de peso $(11,03 \mathrm{~g})$, \% de ganho de peso $(249,21 \%)$, taxa de crescimento específico $(1,39)$ e melhor taxa de conversão alimentar $(1,20)$ foram registrados por peixes alimentados com TD12. Além disso, 0 mesmo nível aumentou a proteína bruta $(59,26 \%)$ e a gordura $(16,04 \%)$, sendo significativamente diferente $(p<0,05)$ do controle. Conclusivamente, a adição de fitase acidificada (CA; 2,5\%, PHY; 750 FTU / kg) em TD12 (CSM = 50\%) levou a um melhor crescimento e composição próxima de alevinos de L. rohita.

Palavras-chave: subprodutos vegetais, aquicultura, farinha de peixe, ração econômica, composição corporal.

\section{Introduction}

The expansion of aquaculture sector depends upon the growth of aquafeed products (Al-Zayat, 2019). Human population is increasing at an exponential rate worldwide which necessitates the continuous supply of food for human life. This sector is aiming to provide protein rich food to the protein starving world. Feed cost covers approximately 70\% of the total farming budget (Dossou et al., 2018). Protein source in the form of fish meal is considered as an important ingredient for feed formulation while its cost and scarce availability limited its use in fish nutrition (Goswami et al.,

*e-mail: drmakhdoom90@gmail.com; shafaqataligill@gcuf.edu.pk

Received: January 20, 2021 - Accepted: February 10, 2021 
2020). Since last few years, the quest for cost effective and nutrient rich ingredients is high on the agenda by a number of fish nutritionists; so, to culture aquatic animals in an economical way (Froehlich et al., 2018).

Now-a-days, the forefront trend is to replace fish meal by the most viable feed stuff i.e., plant meal (Daniel, 2018). It has become an inevitable issue to find cost-effective and highly nutritious plant protein sources for fish feed formulation. Growth promoting potential of various plant meals like soybean meal (Chu et al., 2016), Moringa oleifera by-products meal (Shahzad et al., 2021) and corn gluten meal (Hussain et al., 2018) has been verified by different researchers. CSM is one of the important protein sources (23-53\%) and thought as highly valuable for its cheaper cost and local availability (Sun et al., 2015). After soybean and canola meal, it is the third largest oilseed meal product in the world. It is a rich source of essential amino acid arginine, which is even higher than that of fishmeal and soybean meal (EI-Saidy and Gaber, 2004). Several studies have confirmed its inclusion in the diets of Carassius auratus gibelio (Gui and Zhou, 2010), Oplegnathus fasciatus (Lim and Lee, 2009) and Oreochromis niloticus (Yue and Zhou, 2008).

In plants, most of the phosphorus is found in the form of phytate and phytic acid which is hardly assimilated by agastric or monogastric fishes (NRC, 1993). This phytate complex can only be broken down by the addition of exogenous enzymes like phytase which improves digestibility in gut, nutrient availability to fish and hematology of different fish species (Shahzad et al., 2017). Furthermore, phytase maximizes the absorption of chelated minerals and nutrients present in plant by-products meal (Shahzad et al., 2021). Having this potential, exogenous enzymes are being evaluated on a wider scale (Hlophe-Ginindza et al., 2016). Due to the differences in feeding habits and digestive potential, the activity of digestive enzymes varies in different fish species (Iqbal et al., 2016). Furthermore, organic acids are proving to be a promising dietary additive to improve intestinal health and growth performance (Hassan et al., 2015). Citric acid (CA) has become the one of the world's most usable organic acid (Sauer et al., 2008). Due to its unique flavor and high buffering capacity, it is being used in food, pharmaceutical and other industries (Yin et al., 2015). Recent studies have found positive effects of organic acids on the activity of digestive enzymes which led to improved growth performance (Castillo et al., 2014; Ebrahimi et al., 2017). Supplementation of CA decreases the pH in digestive tract of fish (Baruah et al., 2005). Both CA and PHY not only improve intestinal physiology but also enhance growth, immune response and mineralization in fish body (Emami et al., 2013).

Indian major carps are known as highly cultured fish species around the globe (FAO, 2015). Amidst these, L. rohita is the most popular fish species and considered as the key species in fresh water aquaculture due to its fast growth rate, great economic value, delicious flesh quality, balanced amino acids profile and better disease resistance (Bharathi et al., 2013). So, the aim of the current study was to find out the best level of CA and PHY treated CSM diets for commercially important specie i.e., L. rohita, to improve its growth performance and proximate composition.

\section{Materials and Methods}

\subsection{Fish and experimental conditions}

This study was conducted in the Fish Nutrient Laboratory, Department of Zoology, Government College University, Faisalabad, Pakistan (Latitude $31.4166^{\circ} \mathrm{N}$ and Longitude $73.0707^{\circ} \mathrm{E}$ ). L. rohita fingerlings of average $4.51 \mathrm{~g}$ initial weight were purchased from Government Seed Hatchery, Satiana road, Faisalabad and kept in V-shaped tanks for acclimation to laboratory conditions. Initially, fingerlings were fed with basal diet @5\% body weight once daily to the apparent satiation (Allan and Rowland, 1992). Before the start of feeding trial, fingerlings were given a dip prophylactically in $\mathrm{NaCl}$ solution $(5 \mathrm{~g} / \mathrm{L})$, so to get rid of fungal and bacterial pathogens (Rowland and Ingram, 1991). Parameters such as temperature, $\mathrm{pH}$ and dissolved oxygen were checked daily that should be between $25.9-29.5^{\circ} \mathrm{C}, 7.3-8.5$ and $5.4-7.5 \mathrm{mg} / \mathrm{L}$, respectively.

\subsection{Experimental design}

Fish rearing system was comprised of $48 \mathrm{~V}$-shaped tanks representing 16 groups; in triplicate fashion. These tanks were supplied with fresh water and air supply, so, to maintain dissolved oxygen level. A total of 720 fingerlings of initial weight $(4.51 \mathrm{~g}$ ) were stocked in each tank with 15 fish stocking density. Sixteen test diets $\left(\mathrm{TD}_{1}, \mathrm{TD}_{2}, \mathrm{TD}_{3}\right.$, $\mathrm{TD}_{4}, \mathrm{TD}_{5}, \mathrm{TD}_{6}, \mathrm{TD}_{7}, \mathrm{TD}_{8}, \mathrm{TD}_{9}, \mathrm{TD}_{10}, \mathrm{TD}_{11}, \mathrm{TD}_{12}, \mathrm{TD}_{13}, \mathrm{TD}_{14}$, $\mathrm{TD}_{15}$ and $\left.\mathrm{TD}_{16}\right)$ in $3 \times 3$ factorial arrangement was prepared by replacing FM with CSM at levels of $0 \%, 25 \%, 50 \%$ and $75 \%$ supplemented with CA (0 and 2.5\%) and PHY (0 and $750 \mathrm{FTU} / \mathrm{kg}$ ). Each test diet was allocated to triplicate tanks by using Completely Randomized Design (CRD).

\subsection{Formulation of pellets and feeding technique}

All feed ingredients were purchased from commercial feed mill and analyzed for chemical composition following standard procedures of AOAC (2005) before formulation of experimental diets. Diet composition of nutrients showed that there was an equal amount of nutrients in all the CSM based test diets including the control diet as shown in Table 1 . Feed components were grinded to pass through $0.5 \mathrm{~mm}$ sieve size. Fish oil was poured in mixture and mixed for 5 minutes. To prepare suitable dough, 10-15\% distilled water was added (Lovell, 1989). To get feed pellets, previously made dough was processed by pelleting machine (Model SYSLG30-5 experimental extruder). Phytase was later on sprayed on test diets as defined by Robinson et al. (2002). After drying, pellets diameter was adjusted according to fish size and stored at $4{ }^{\circ} \mathrm{C}$ to keep it oxidation-free. The actual feeding trial prolonged for 12 weeks (90 days). Fish were hand fed at the rate of the $5 \% /$ day of their total biomass. The total amount of feed was divided into two halves and offered to the fish in morning (8:00 am) and afternoon (12:00 pm). 
Table 1. Ingredients composition (\%) of test diets.

\begin{tabular}{|c|c|c|c|c|c|c|c|c|c|c|c|}
\hline Test diets & 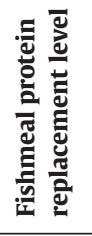 & 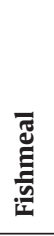 & 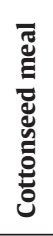 & 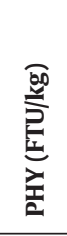 & $\frac{\grave{d}}{\overleftarrow{\delta}}$ & 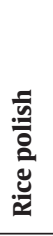 & 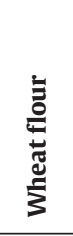 & $\begin{array}{l}\overline{0} \\
\bar{n} \\
\frac{\bar{n}}{2}\end{array}$ & 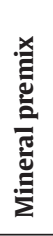 & 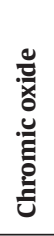 & 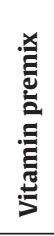 \\
\hline $\mathrm{TD}_{1}$ & $0 \%$ & 48 & 18 & 0 & 0 & 3 & 22 & 6 & 1 & 1 & 1 \\
\hline $\mathrm{TD}_{2}$ & & 48 & 18 & & 2.5 & 3 & 19.5 & 6 & 1 & 1 & 1 \\
\hline $\mathrm{TD}_{3}$ & & 48 & 18 & 750 & 0 & 3 & 22 & 6 & 1 & 1 & 1 \\
\hline $\mathrm{TD}_{4}$ & & 48 & 18 & & 2.5 & 3 & 19.5 & 6 & 1 & 1 & 1 \\
\hline $\mathrm{TD}_{5}$ & $25 \%$ & 36 & 35 & 0 & 0 & 3 & 17 & 6 & 1 & 1 & 1 \\
\hline $\mathrm{TD}_{6}$ & & 36 & 35 & & 2.5 & 3 & 14.5 & 6 & 1 & 1 & 1 \\
\hline $\mathrm{TD}_{7}$ & & 36 & 35 & 750 & 0 & 3 & 17 & 6 & 1 & 1 & 1 \\
\hline $\mathrm{TD}_{8}$ & & 36 & 35 & & 2.5 & 3 & 14.5 & 6 & 1 & 1 & 1 \\
\hline $\mathrm{TD}_{9}$ & $50 \%$ & 24 & 53 & 0 & 0 & 3 & 11 & 6 & 1 & 1 & 1 \\
\hline $\mathrm{TD}_{10}$ & & 24 & 53 & & 2.5 & 3 & 8.5 & 6 & 1 & 1 & 1 \\
\hline $\mathrm{TD}_{11}$ & & 24 & 53 & 750 & 0 & 3 & 11 & 6 & 1 & 1 & 1 \\
\hline $\mathrm{TD}_{12}$ & & 24 & 53 & & 2.5 & 3 & 8.5 & 6 & 1 & 1 & 1 \\
\hline $\mathrm{TD}_{13}$ & $75 \%$ & 12 & 71 & 0 & 0 & 3 & 5 & 6 & 1 & 1 & 1 \\
\hline $\mathrm{TD}_{14}$ & & 12 & 71 & & 2.5 & 3 & 2.5 & 6 & 1 & 1 & 1 \\
\hline $\mathrm{TD}_{15}$ & & 12 & 71 & 750 & 0 & 3 & 5 & 6 & 1 & 1 & 1 \\
\hline $\mathrm{TD}_{16}$ & & 12 & 71 & & 2.5 & 3 & 2.5 & 6 & 1 & 1 & 1 \\
\hline
\end{tabular}

The unconsumed diet was siphoned out from every tank, dried and weighed for determination of daily feed intake.

\subsection{Growth study}

To determine growth performance of fish, weight measurement was undertaken every fortnightly. Fish from each tank was caught up smoothly and then dried using tissue. Finally, its length and weight were noted down. Standard formulae (NRC, 1993) were used to determine growth performance (Equations 1, 2 and 3).

$$
\begin{aligned}
& \text { Weight Gain } \%=\frac{\text { Final Weight }(\mathrm{g})-\text { Initial Weight }(\mathrm{g})}{\text { Initial Weight }} \times 100 \\
& \mathrm{FCR}=\frac{\text { Total dry feed intake }(\mathrm{g})}{\text { Wet weight gain }(\mathrm{g})} \\
& \mathrm{SGR}=\frac{\text { Final Weight }(\mathrm{g})-\text { Initial Weight }(\mathrm{g})}{\text { No of trial days }} \times 100
\end{aligned}
$$

\subsection{Determination of whole-body composition}

After 90 days of feeding experiment, 5 unstressed fish of $L$. rohita were taken from each tank and sacrificed for determination of proximate composition following standard procedures of AOAC (2005). Then fish whole body samples were air dried and analyzed for determination of body composition (Korhonen et al., 1990). By a mortar and pestle, whole fish body was homogenized and examined by standard techniques; crude fat by petroleum ether extraction through Soxhlet system, ash by ignition at $650^{\circ} \mathrm{C}$ for 12 hours in an electric furnace to constant weight, crude protein $(\mathrm{N} \times 6.25)$ contents by micro Kjeldahl apparatus, moisture by oven-drying at $105^{\circ} \mathrm{C}$ for $12 \mathrm{~h}$; crude fiber as loss on ignition of desiccated residues that are lipid free after breakdown with $1.25 \% \mathrm{NAOH}$ and $1.25 \% \mathrm{H}_{2} \mathrm{SO}_{4}$. Total carbohydrates were calculated by following formula i.e., Total carbohydrates $(\%)=100-(\mathrm{EE} \%+\mathrm{CP} \%+\mathrm{Ash} \%+\mathrm{CF} \%)$.

\subsection{Statistical analysis}

Data of growth performance and proximate composition was subjected to three-way Analysis of Variance (Steel et al., 1996). By Tukey's Honesty Significant Difference Test, the differences among treatments were compared and determined significant at $\mathrm{p}<0.05$ (Snedecor and Cochran, 1991). For statistical analysis, the Co-Stat computer software (Version 6.303, PMB 320, Monterey, CA, 93940 USA) was used.

\section{Results}

\subsection{Growth performance}

Table 2 shows the growth performance of $L$. rohita fingerlings fed on acidified phytase supplemented CSM based diets. The results demonstrated that growth 
Table 2. Growth performance of $L$. rohita fingerlings fed on CSM based test diets.

\begin{tabular}{|c|c|c|c|c|c|c|c|}
\hline Test diets & $\begin{array}{l}\text { Fishmeal protein } \\
\text { replacement level }\end{array}$ & PHY (FTU/kg) & CA (\%) & IW (g) & FW (g) & WG (g) & SGR \\
\hline $\mathrm{TD}_{1}$ & $0 \%$ & 0 & 0 & 4.48 & $10.77^{\mathrm{j}}$ & $6.30^{\mathrm{k}}$ & $0.98^{\mathrm{i}}$ \\
\hline $\mathrm{TD}_{2}$ & & & 2.5 & 4.57 & $11.24^{\mathrm{h}}$ & $6.67^{\mathrm{j}}$ & $1.00^{\mathrm{h}}$ \\
\hline $\mathrm{TD}_{3}$ & & 750 & 0 & 4.24 & $10.94^{\mathrm{i}}$ & $6.70^{\mathrm{j}}$ & $1.05^{\mathrm{g}}$ \\
\hline $\mathrm{TD}_{4}$ & & & 2.5 & 4.30 & $12.26^{\mathrm{e}}$ & $7.96^{\mathrm{f}}$ & $1.16^{\mathrm{e}}$ \\
\hline $\mathrm{TD}_{5}$ & $25 \%$ & 0 & 0 & 4.64 & $11.79^{g}$ & $7.15^{\mathrm{i}}$ & $1.04^{8}$ \\
\hline $\mathrm{TD}_{6}$ & & & 2.5 & 4.76 & $12.38^{\mathrm{e}}$ & $7.63^{\mathrm{g}}$ & $1.06^{\mathrm{g}}$ \\
\hline $\mathrm{TD}_{7}$ & & 750 & 0 & 4.67 & $13.37^{c}$ & $8.70^{c}$ & $1.17^{\mathrm{e}}$ \\
\hline $\mathrm{TD}_{8}$ & & & 2.5 & 4.63 & $14.73^{\mathrm{b}}$ & $10.11^{b}$ & $1.29^{\mathrm{b}}$ \\
\hline $\mathrm{TD}_{9}$ & $50 \%$ & 0 & 0 & 4.59 & $13.29^{c}$ & $8.70^{c}$ & $1.18^{\mathrm{e}}$ \\
\hline $\mathrm{TD}_{10}$ & & & 2.5 & 4.43 & $13.27^{c}$ & $8.83^{c}$ & $1.22^{\mathrm{d}}$ \\
\hline $\mathrm{TD}_{11}$ & & 750 & 0 & 4.26 & $13.02^{\mathrm{d}}$ & $8.77^{c}$ & $1.24^{c}$ \\
\hline $\mathrm{TD}_{12}$ & & & 2.5 & 4.43 & $15.46^{\mathrm{a}}$ & $11.03^{\mathrm{a}}$ & $1.39^{\mathrm{a}}$ \\
\hline $\mathrm{TD}_{13}$ & $75 \%$ & 0 & 0 & 4.47 & $12.13^{\mathrm{f}}$ & $7.66^{\mathrm{g}}$ & $1.11^{\mathrm{f}}$ \\
\hline $\mathrm{TD}_{14}$ & & & 2.5 & 4.33 & $11.79^{\mathrm{g}}$ & $7.46^{\mathrm{h}}$ & $1.11^{\mathrm{f}}$ \\
\hline $\mathrm{TD}_{15}$ & & 750 & 0 & 4.37 & $12.46^{\mathrm{e}}$ & $8.09^{e}$ & $1.16^{\mathrm{e}}$ \\
\hline $\mathrm{TD}_{16}$ & & & 2.5 & 4.46 & $12.90^{\mathrm{d}}$ & $8.44^{\mathrm{d}}$ & $1.18^{\mathrm{e}}$ \\
\hline \multicolumn{4}{|c|}{ Pool Standard Error (PSE) } & 0.05 & 0.12 & 0.12 & 0.01 \\
\hline
\end{tabular}

Means within columns having different superscripts are significantly different at $\mathrm{p}<0.05$. Data are means of three replicates.

parameters were improved by supplementation of PHY and CA and their additive response brought maximum growth of fish. Dietary inclusion of both CA and PHY reduced gut $\mathrm{pH}$ as the concentration of dose was increased. Optimal fish growth $(\mathrm{p}<0.05)$ was obtained by using $\mathrm{TD}_{12}$ having acidified phytase (2.5\% CA, $750 \mathrm{FTU} / \mathrm{kg}$ ) and FM+CSM $(50+50 \%)$ as compared to those fed on control diet and other test diets. Figure 1 and 2 showed the highest values of WG (11.03g), WG\% (249.21\%), FCR (1.20) and SGR (1.39) at this level followed by $\mathrm{TD}_{8}(10.83 \mathrm{~g}, 218.5 \%, 1.48,1.29)$ having only CA (2.5\%). Possibly, CA alone reduced intestinal pH to the level responsible for release of chelated nutrients which may led to improved fish growth. On the other hand, lowest WG (6.30g), WG\% (140.82\%) and SGR (0.98) were noted in fingerlings fed on $\mathrm{TD}_{1}$ (no supplementation) having more inclusion of FM. High FCR value (2.16) also predicted that least amount of nutrients were made part of fish body. Conclusively, the growth of $L$. rohita was improved with the increase in CSM protein up to $50 \%$ and subsequent decrease in FM, along with supplementation of CA (2.5\%) and PHY (750 FTU/kg) and started decrease with any further inclusion of CSM.

\subsection{Proximate composition}

The effect of acidified phytase supplemented CSM based diet on proximate composition of $L$. rohita fingerlings is illustrated in Table 3 and Figure 3. Our results made it clear that nutrient composition of fish was optimally improved by feeding $\mathrm{TD}_{12}$ having acidified phytase $(750 \mathrm{FTU} / \mathrm{kg}$, $2.5 \%$ CA) CSM (50\%) based diet as compared to those fed on control diet. Significant differences in terms of crude

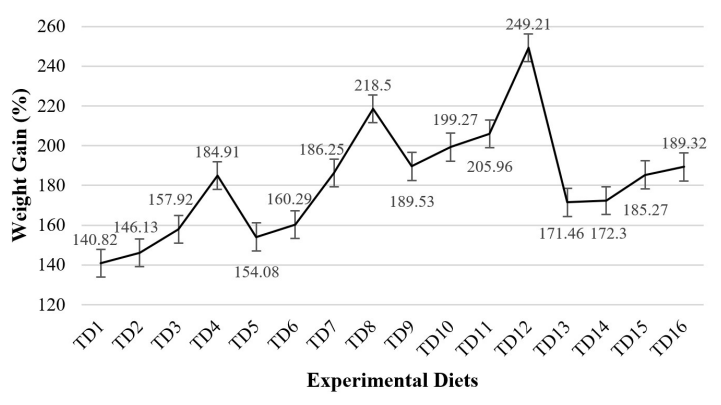

Figure 1. Graph showing weight gain (\%) of L. rohita fingerlings fed on acidified phytase CSM based diets.

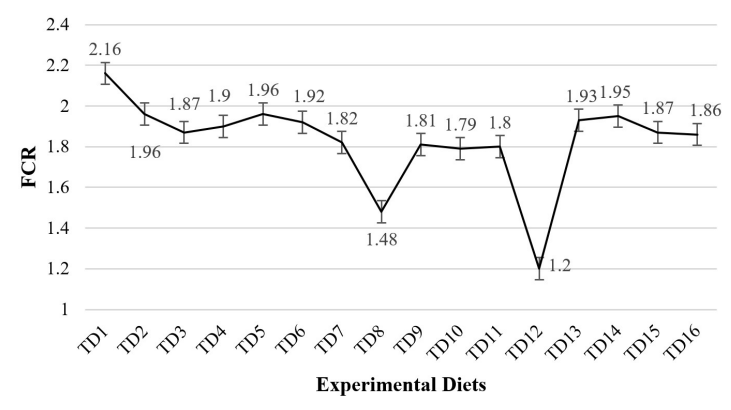

Figure 2. Graph showing FCR of $L$. rohita fingerlings fed on acidified phytase CSM based diets.

protein (59.26\%) and crude fat (16.04\%) were prevalent in fish body when fed at $\mathrm{TD}_{12}$. It confers the idea that phytate complex was degraded maximally at this level and released 
Table 3. Proximate composition (\%) of $L$. rohita fed with acidified phytase supplemented CSM based diets.

\begin{tabular}{|c|c|c|c|c|c|c|c|}
\hline Test diets & 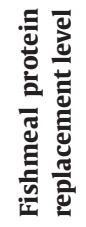 & 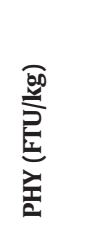 & 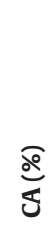 & 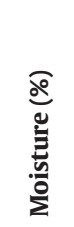 & 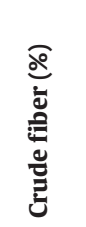 & $\frac{\bar{Ð}}{\overline{\frac{9}{2}}}$ & 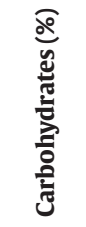 \\
\hline $\mathrm{TD}_{1}$ & $0 \%$ & 0 & 0 & $7.25^{\mathrm{a}}$ & $2.46^{a}$ & $13.25^{\mathrm{a}}$ & $19.00^{\mathrm{a}}$ \\
\hline $\mathrm{TD}_{2}$ & & & 2.5 & $7.19^{a}$ & $2.38^{\mathrm{b}}$ & $11.94^{\mathrm{b}}$ & $18.80^{\mathrm{b}}$ \\
\hline $\mathrm{TD}_{3}$ & & 750 & 0 & $7.03^{a}$ & $2.25^{d}$ & $10.61^{\mathrm{d}}$ & $17.74^{\mathrm{d}}$ \\
\hline $\mathrm{TD}_{4}$ & & & 2.5 & $6.95^{\mathrm{a}}$ & $1.94^{\mathrm{h}}$ & $8.70^{g}$ & $16.12^{\mathrm{h}}$ \\
\hline $\mathrm{TD}_{5}$ & $25 \%$ & 0 & 0 & $7.02^{\mathrm{a}}$ & $2.31^{\mathrm{c}}$ & $11.45^{c}$ & $18.02^{c}$ \\
\hline $\mathrm{TD}_{6}$ & & & 2.5 & $6.93^{\mathrm{a}}$ & $2.19^{e}$ & $10.38^{e}$ & $17.49^{e}$ \\
\hline $\mathrm{TD}_{7}$ & & 750 & 0 & $5.83^{c}$ & $1.78^{\mathrm{j}}$ & $7.98^{\mathrm{i}}$ & $15.46^{j}$ \\
\hline $\mathrm{TD}_{8}$ & & & 2.5 & $5.35^{d}$ & $1.27^{\circ}$ & $6.43^{1}$ & $12.51^{\circ}$ \\
\hline $\mathrm{TD}_{9}$ & $50 \%$ & 0 & 0 & $5.70^{c}$ & $1.60^{1}$ & $7.10^{\mathrm{j}}$ & $14.66^{\mathrm{k}}$ \\
\hline $\mathrm{TD}_{10}$ & & & 2.5 & $6.07^{c}$ & $1.50^{\mathrm{m}}$ & $6.98^{j}$ & $13.32^{\mathrm{m}}$ \\
\hline $\mathrm{TD}_{11}$ & & 750 & 0 & $5.60^{c}$ & $1.36^{\mathrm{n}}$ & $6.81^{\mathrm{k}}$ & $12.97^{n}$ \\
\hline $\mathrm{TD}_{12}$ & & & 2.5 & $5.37^{\mathrm{d}}$ & $1.20^{p}$ & $6.04^{\mathrm{m}}$ & $12.09^{p}$ \\
\hline $\mathrm{TD}_{13}$ & $75 \%$ & 0 & 0 & $6.84^{a}$ & $2.11^{\mathrm{f}}$ & $9.33^{f}$ & $17.29^{f}$ \\
\hline $\mathrm{TD}_{14}$ & & & 2.5 & $6.80^{\mathrm{a}}$ & $2.02^{\mathrm{g}}$ & $9.21^{\mathrm{f}}$ & $16.78^{g}$ \\
\hline $\mathrm{TD}_{15}$ & & 750 & 0 & $6.48^{b}$ & $1.88^{\mathrm{i}}$ & $8.20^{\mathrm{h}}$ & $15.89^{i}$ \\
\hline $\mathrm{TD}_{16}$ & & & 2.5 & $5.91^{\mathrm{c}}$ & $1.65^{\mathrm{k}}$ & $8.00^{\mathrm{i}}$ & $14.35^{1}$ \\
\hline \multicolumn{4}{|c|}{ Pool Standard Error (PSE) } & 0.16 & 0.03 & 0.14 & 0.10 \\
\hline
\end{tabular}

Means within columns having different superscripts are significantly different at $\mathrm{p}<0.05$. Data are means of three replicates.

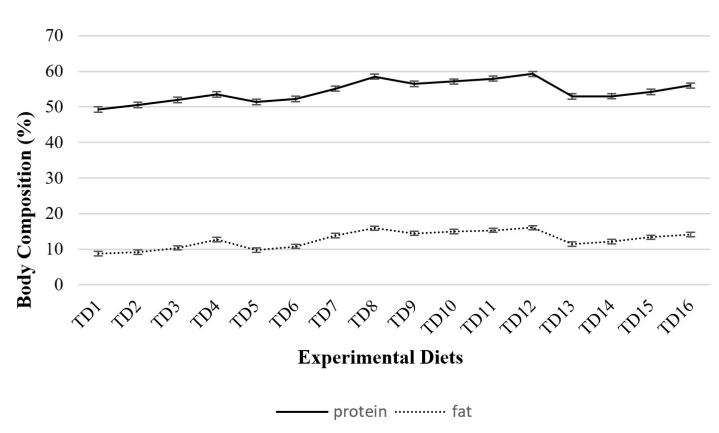

Figure 3. Body composition of $L$. rohita fingerlings fed acidified phytase CSM based diets.

phosphorus to be a part of fish body. Second best values (58.54\%, 15.89\%) were obtained by using $\mathrm{TD}_{8}$ having FM protein replaced by CSM up to $25 \%$ supplemented with CA and PHY at their highest concentration i.e., $2.5 \%$ and $750 \mathrm{FTU} / \mathrm{kg}$, respectively. However, lowest values of protein $(49.30 \%)$ and fat $(8.73 \%)$ were observed in those fed on $\mathrm{TD}_{1}$. The highest values of moisture (7.25\%), crude fiber (2.46\%), crude ash (13.25\%) and carbohydrates (19\%) were also recorded on the same level.

\section{Discussion}

In present study, L. rohita fingerlings fed on CSM based diet supplemented with CA (2.5\%) and PHY (750 FTU $/ \mathrm{kg}$ ) led to improved body parameters like WG\% $(249.21 \%$ ) and FCR (1.20). Similarly, Khaled (2019) reported a significant effect of $1000 \mathrm{FTU} / \mathrm{kg}$ phytase in improving WG (\%), specific growth rate and FCR of Nile tilapia. In line with our studies, Baruah et al. (2007) and Bano and Afzal (2018) in L. rohita and Wang et al. (2009) in Oncorhynchus mykiss found growth promoting results. They proved that supplementation of acidified phytase trigger the phytate hydrolysis by reducing stomach $\mathrm{pH}$ and improved growth was resulted. Luckstadt, (2008) found that citric acid inclusion to phytase deposit $\mathrm{H}^{+}$ions in stomach and enhance nutrient bioavailability. A number of researchers came to the point that supplementation of exogenous enzymes in plant meal based diets helps to mitigate the effects of anti-nutritional factors (Hlophe-Ginindza et al., 2016) and maximum quantity of amino acids become part of fish body (Hussain et al., 2015b). Supporting our results, Singh et al. (2020) found that citric acid (1.5\%) and phytase (1200FTU $/ \mathrm{kg}$ ) positively affected the growth parameters of 0 . mykiss. Meanwhile, improved growth performance in many fish species by addition of phytase in citric acid was observed such as tilapia (Tahoun et al., 2009), 
catfish (Hung et al., 2015) and grass carp (Liu et al., 2014). Hussain et al. (2015a) found positive results in L. rohita fingerlings fed on CSM based diet supplemented with 750 FTU/kg level; just similar to our values and reported best growth performance. On the other hand, Lim and Lee (2009) and Wang et al. (2009) did not find any significant effect of phytase supplemented plant based diets on fingerlings' growth performance. The possible reason can be the thermal inactivation of phytase enzymes during feed formulation, diet composition, storage conditions of feed, plant meal replacement level and fish species (Hassaan et al., 2019).

Supplementation of $750 \mathrm{FTU} / \mathrm{kg}$ phytase with $2.5 \% \mathrm{CA}$ resulted in an interaction and enhanced the whole body composition like crude protein (59.26\%) and crude fat (16.04\%). Similar results were proposed by other researchers following the dietary addition of CA (Hossain et al., 2007; Khajepour and Hosseini, 2012). Recent studies have shown that poor fish carcass composition is due to phytate complex, which usually bounds important nutrients such as $\mathrm{CP}$, EE and gross energy making them unavailable to fish (Cao et al., 2007). Thus, in present research, the acidified phytase supplemented diet enhanced the proximate composition of whole body by acting on chelated complex and increased the availability of nutrients to fingerlings. Similarly, Khajepour and Hosseini (2012) noticed increased crude protein contents in muscles of Huso huso while adding CA (30g/kg) in the diet. Whereas, Liu et al. (2014) and Cao et al. (2008) reported that acidified phytase supplementation decreased body lipids of grass carp and Nile tilapia, respectively.

\section{Conclusions}

Based upon the obtained results, it can be concluded that $\mathrm{TD}_{12}$ having $\mathrm{CSM}$ protein up to $50 \%$ supplemented with $2.5 \% \mathrm{CA}$ and $750 \mathrm{FTU} / \mathrm{kg}$ PHY proved to be the most efficient diet in improving growth performance of $L$. rohita fingerlings. Furthermore, the proximate composition of fish body was also improved by the synergistic effect of CA and PHY. Hence, it assisted in the formulation of cost-effective and eco-friendly feed for L. rohita.

\section{Acknowledgements}

The authors would like to acknowledge HEC Pakistan for providing funds for NRPU Projects \# 20-4892/NRPU/R\&D/ HEC/14/1145 and 5649/Punjab/NRPU/R\&D/HEC/2016 to conduct this research work.

\section{References}

ALLAN, G.L. and ROWLAND, S.J., 1992. Development of an experimental diet for silver perch (Bidyanus bidyanus). Austasia Aquaculture, vol. 6, pp. 39-40.

AL-ZAYAT, A.H.M.E.D., 2019. Effect of different levels of citric acid as supplementation on growth performance, feed utilization, body composition, water quality, and blood profile of Monosex Male Nile Tilapia (Oreochromis niloticus) fingerlings. Egyptian
Journal of Aquatic Biology and Fisheries, vol. 23, no. 3, pp. 611624. http://dx.doi.org/10.21608/ejabf.2019.63104.

ASSOCIATION OF OFFICIAL ANALYTICAL CHEMISTS - AOAC, 2005. Official methods of analysis. 15th ed. Washington: AOAC, $1094 \mathrm{p}$.

BANO, N. and AFZAL, M., 2018. Synchronized effect of citric acid and phytase supplementation on growth performance and nutrient digestibility of Labeo rohita. Aquaculture Nutrition, vol. 24, no. 2, pp. 786-792. http://dx.doi.org/10.1111/anu.12607.

BARUAH, K., PAL, A.K., SAHU, N.P., JAIN, K.K., MUKHERJEE, S.C. and DEBNATH, D., 2005. Dietary protein level, microbial phytase, citric acid and their interactions on bone mineralization of Labeo rohita (Hamilton) juveniles. Aquaculture Research, vol. 36, no. 8, pp. 803-812. http://dx.doi.org/10.1111/j.1365-2109.2005.01290.x.

BARUAH, K., SAHU, N.P., PAL, A.K., JAIN, K.K., DEBNATH, D. and MUKHERJEE, S.C., 2007. Dietary microbial phytase and citric acid synergistically enhances nutrient digestibility and growth performance of Labeo rohita (Hamilton) juveniles at sub-optimal protein level. Aquaculture Research, vol. 38, no. 2, pp. 109-120. http://dx.doi.org/10.1111/j.1365-2109.2006.01624.x.

BHARATHI, P., CHITTEM, S. and KUNDA, S.K., 2013. Effect of dietary omega-3-fatty acid diets on growth and physico-chemical parameters of cultured water in fingerlings of Labeo rohita. International Journal of Innovative Research in Science, Engineering and Technology, vol. 2, no. 8, pp. 3716-3722.

CAO, L., WANG, W., YANG, C., YANG, Y., DIANA, J., YAKUPITIYAGE, A., LUO, Z. and LI, D., 2007. Application of microbial phytase in fish feed. Enzyme and Microbial Technology, vol. 40, no. 4, pp. 497-507. http://dx.doi.org/10.1016/j.enzmictec.2007.01.007.

CAO, L., YANG, Y., WANG, W.M., YAKUPITIYAGE, A., YUAN, D.R. and DIANA, J.S., 2008. Effects of pretreatment with microbial phytase on phosphorous utilization and growth performance of Nile tilapia (Oreochromis niloticus). Aquaculture Nutrition, vol. 14, no. 2, pp. 99-109. http://dx.doi.org/10.1111/j.13652095.2007.00508.x.

CASTILLO, S., ROSALES, M., POHLENZ, C. and GATLIN III, D.M., 2014. Effects of organic acids on growth performance and digestive enzyme activities of juvenile red drum Sciaenops ocellatus. Aquaculture, vol. 433, pp. 6-12. http://dx.doi.org/10.1016/j. aquaculture.2014.05.038.

CHU, Z.J., YU, D.H., DONG, G.F. and GONG, S.Y., 2016. Partial replacement of fish meal by soybean meal with or without methionine and phytase supplement in diets for juvenile Chinese sucker, Myxocyprinus asiaticus. Aquaculture Nutrition, vol. 22, no. 5, pp. 989-996. http://dx.doi.org/10.1111/anu.12318.

DANIEL, N., 2018. A review on replacing fish meal in aqua feeds using plant protein sources. International Journal of Fisheries and Aquatic Studies, vol. 6, no. 2, pp. 164-179.

DOSSOU, S., KOSHIO, S., ISHIKAWA, M., YOKOYAMA, S., DAWOOD, M.A.O., EL BASUINI, M.F., EL-HAIS, A.M. and OLIVIER, A., 2018. Effect of partial replacement of fish meal by fermented rapeseed meal on growth, immune response and oxidative condition of red sea bream juvenile, Pagrus major. Aquaculture, vol. 490, pp. 228-235. http://dx.doi.org/10.1016/j.aquaculture.2018.02.010.

EBRAHIMI, M., DAEMAN, N.H., CHONG, C.M., KARAMI, A., KUMAR, V., HOSEINIFAR, S.H. and ROMANO, N., 2017. Comparing the effects of different dietary organic acids on the growth, intestinal short-chain fatty acids, and liver histopathology of red hybrid tilapia (Oreochromis sp.) and potential use of these as preservatives. Fish Physiology and Biochemistry, vol. 43, no. 4, pp. 1195-1207. http://dx.doi.org/10.1007/s10695-017-0365-0. PMid:28349418.

EI-SAIDY, D.M.S.D. and GABER, M.M., 2004. Use of cottonseed meal supplement with iron for detoxification of gossypol as a 
replacement of fish meal in Nile tilapia, Oreochromis niloticus (L.) diets. Aquaculture Research, vol. 35, no. 9, pp. 859-869. http://dx.doi.org/10.1111/j.1365-2109.2004.01077.x.

EMAMI, N.K., NAEINI, S.Z. and RUIZ-FERIA, C.A., 2013. Growth performance, digestibility, immune response and intestinal morphology of male broilers fed phosphorus deficient diets supplemented with microbial phytase and organic acids. Livestock Science, vol. 157, no. 2-3, pp. 506-513. http://dx.doi. org/10.1016/j.livsci.2013.08.014

FOOD AND AGRICULTURE ORGANIZATION OF THE UNITED NATIONS - FAO, 2015 [viewed 20 January 2021]. Fish stat database [online]. Available from: http://faostat.fao.org/site/629/default.aspx

FROEHLICH, H.E., RUNGE, C.A., GENTRY, R.R., GAINES, S.D. and HALPERN, B.S., 2018. Comparative terrestrial feed and land use of an aquaculture-dominant world. Proceedings of the National Academy of Sciences of the United States of America, vol. 115, no. 20, pp. 5295-5300. http://dx.doi.org/10.1073/pnas.1801692115. PMid:29712823.

GOSWAMI, R.K., SHRIVASTAV, A.K., SHARMA, J.G., TOCHER, D.R. and CHAKRABARTI, R., 2020. Growth and digestive enzyme activities of rohu Labeo rohita fed diets containing macrophytes and almond oil-cake. Animal Feed Science and Technology, vol. 263, pp. 114456. http://dx.doi.org/10.1016/j.anifeedsci.2020.114456. PMid:32421037.

GUI, J. and ZHOU, L., 2010. Genetic basis and breeding application of clonal diversity and dual reproduction modes in polyploid Carassius auratus gibelio. Science China. Life Sciences, vol. 53, no. 4, pp. 409-415. http://dx.doi.org/10.1007/s11427-010-0092-6. PMid:20596906.

HASSAAN, M.S., EL-SAYED, A.I.M., SOLTAN, M.A., IRAQI, M.M., GODA, A.M., DAVIES, S.J., EL-HAROUN, E.R. and RAMADAN, H.A., 2019. Partial dietary fish meal replacement with cottonseed meal and supplementation with exogenous protease alters growth, feed performance, hematological indices and associated gene expression markers (GH, IGF-I) for Nile tilapia, Oreochromis niloticus. Aquaculture, vol. 503, pp. 282-292. http://dx.doi. $\operatorname{org} / 10.1016 / j$.aquaculture.2019.01.009.

HASSAN, H.M.A., YOUSSEF, A.W., ALI, H.M. and MOHAMED, M.A., 2015. Adding phytogenic material and/or organic acids to broiler diets: effect on performance, nutrient digestibility and net profit. Asian Journal of Political Science, vol. 9, no. 2, pp. 97-105. http://dx.doi.org/10.3923/ajpsaj.2015.97.105.

HLOPHE-GININDZA, S.N., MOYO, N.A., NGAMBI, J.W. and NCUBE, I., 2016. The effect of exogenous enzyme supplementation on growth performance and digestive enzyme activities in Oreochromis mossambicus fed kikuyu-based diets. Aquaculture Research, vol.47, no. 12, pp. 3777-3787. http://dx.doi.org/10.1111/ are.12828.

HOSSAIN, M.A., PANDEY, A. and SATOH, S., 2007. Effects of organic acids on growth and phosphorus utilization in red sea bream Pagrus major. Fisheries Science, vol. 7, pp. 1309-1317. http:// dx.doi.org/10.1111/j.1444-2906.2007.01469.x.

HUNG, L.T., THANH, N.T., PHAM, M.A. and BROWDY, C.L., 2015. A comparison of the effect of dietary fungal phytase and dicalcium phosphate supplementation on growth performances, feed and phosphorus utilization of tra catfish juveniles (Pangasianodon hypophthalmus Sauvage, 1878). Aquaculture Nutrition, vol. 21, no. 1, pp. 10-17. http://dx.doi.org/10.1111/anu.12134.

HUSSAIN, S.M., AFZAL, M., JAVID, A., HUSSAIN, A.I., ALI, Q., MUSTAFA, I., CHATHA, S.A.S., SHAH, S.Z.H., HUSSAIN, M. and ULLAH, M.I., 2015a [viewed 20 January 2021]. Efficacy of phytase supplementation on growth performance and mineral digestibility of Labeo rohita fingerlings fed on cottonseed meal based diet. Pakistan Journal of Zoology [online], vol. 47, no. 3, pp. 699-709. Available from: http://www.zsp.com.pk/ pdf47/699-709\%2

HUSSAIN, S.M., SHAHZAD, M.M., AFZAL, M., JAVID, A., MUBARIK, M.S., SHAH, S.Z.H., HUSSAIN, M., AHMAD, S., ARSALAN, M.Z.H., MANZOOR, R. and RIAZ, D., 2015b [viewed 20 January 2021]. Efficacy of phytase enzyme for increasing mineral digestibility of Cirrhinus mrigala fingerlings fed on soybean meal-based diet. Pakistan Journal of Zoology [online], vol. 47, no. 6, pp. 1807-1816. Available from: http://www.zsp.com.pk/pdf47/1807-1816

HUSSAIN, S.M., AHMAD, N., JAVID, A., SHAHZAD, M.M., HUSSAIN, M. and ARSALAN, M.Z.U.H., 2018. Effects of phytase and citric acid supplemented corn gluten (30\%) meal-based diets on the mineral digestibility of Cirrhinus mrigala fingerlings. Turkish Journal of Fisheries and Aquatic Sciences, vol. 18, pp. 501-507. http://dx.doi.org/10.4194/1303-2712-v18_4_01.

IQBAL, K.J., ASHRAF, M., JAVID, A., KHAN, N., ABBAS, F., HAFEEZUR-REHMAN, M., RAFIQUE, M.K., RASOOL, F., AZMAT, H. and ALTAF, M., 2016 [viewed 20 January 2021]. Effect of different plant and animal origin (fishmeal) feeds on digestive enzyme activity and haematology of juvenile Labeo rohita. Pakistan Journal of Zoology [online], vol. 48, no. 1, pp. 201-207. Available from: http://www.zsp.com.pk/vol-48[1].html

KHAJEPOUR, F. and HOSSEINI, S.A., 2012. Citric acid improves growth performance and phosphorus digestibility in Beluga (Huso huso) fed diets where soybean meal partly replaced fish meal. Animal Feed Science and Technology, vol. 171, no. 1, pp. 68-73. http://dx.doi.org/10.1016/j.anifeedsci.2011.10.001.

KHALED, A.A., 2019. Influence of supplemental microbial phytase on growth performance parameters and expression of immunerelated genes of Nile tilapia (Oreochromis niloticus). Middle East Journal of Agriculture Research, vol. 8, no. 2, pp. 600-610.

KORHONEN, R.W., LANIER, T.C. and GIESBRECHT, F., 1990. An evaluation of simple methods for following rigor development in fish. Journal of Food Science, vol. 55, no. 2, pp. 346-348. http:// dx.doi.org/10.1111/j.1365-2621.1990.tb06759.x.

LIM, S.J. and LEE, K.J., 2009. Partial replacement of fish meal by cottonseed meal and soybean meal with iron and phytase supplementation for parrot fish Oplegnathus fasciatus. Aquaculture, vol. 290, no. 3-4, pp. 283-289. http://dx.doi. org/10.1016/j.aquaculture.2009.02.018.

LIU, L., ZHOU, Y., WU, J., ZHANG, W., ABBAS, K., XU-FANG, L. and LUO, Y., 2014. Supplemental graded levels of neutral phytase using pretreatment and spraying methods in the diet of grass carp, Ctenopharyngodon idellus. Aquaculture Research, vol. 45, no. 12, pp. 1932-1941. http://dx.doi.org/10.1111/are.12145.

LOVELL, T., 1989. Nutrition and feeding of fish. New York: Van Nostrand Reinhold, vol. 260. http://dx.doi.org/10.1007/9781-4757-1174-5.

LUCKSTADT, C., 2008. The use of acidifiers in fish nutrition. Perspectives in Agriculture, Veterinary Science, Nutrition and Natural Resources, vol. 3, no. 044, pp. 1-8. http://dx.doi. org/10.1079/PAVSNNR20083044.

NATIONAL RESEARCH COUNCIL - NRC, 1993. Nutrient requirements of fish. Washington, DC: National Academy Press, pp. 114.

ROBINSON, E.H., LI, M.H. and MANNING, B.B., 2002. Comparison of microbial phytase and dicalcium phosphate for growth and bone mineralization of pond-raised channel catfish, Ictalurus punctatus. Journal of Applied Aquaculture, vol. 12, no. 3, pp. 81-88. http://dx.doi.org/10.1300/J028v12n03_08.

ROWLAND, S.J. and INGRAM, B.A., 1991. Diseases of Australian native fishes. New South Wales: Department of Agriculture. Fisheries Bulletin, no. 4. 
SAUER, M., PORRO, D., MATTANOVICH, D. and BRANDUARDI, P., 2008. Microbial production of organic acids: expanding the markets. Trends in Biotechnology, vol. 26, no. 2, pp. 100-108. http://dx.doi.org/10.1016/j.tibtech.2007.11.006. PMid:18191255.

SHAHZAD, M.M., HUSSAIN, S.M., JABEEN, F., HUSSAIN, A.I., AHMAD, S., ASHRAF, A. and ARSALAN, M.Z.H., 2017. Effect of phytase supplementation on mineral digestibility to Catla catla fingerlings fed Moringa oleifera leaf meal based test diets. Punjab University Journal of Zoology, vol. 32, no. 1, pp. 65-73.

SHAHZAD, M.M., RAFIQUE, T., HUSSAIN, S.M., HUSSAIN, Z., ZAHOOR, M.Y., HUSSAIN, M., REHMAN, R.A., AHMAD, N., LIAQUAT, I. and BASHIR, S., 2021. Effect of phytase supplemented Moringa by-products based diets on the performance of Oreochromis niloticus fingerlings. Journal of Animal and Plant Sciences, vol. 31, no. 1, pp. 288-295. http://dx.doi.org/10.36899/japs.2021.1.0216.

SINGH, S.K., BHANDARI, M.P. and TIMALSINA, P., 2020. Effect of dietary inclusion of citric acid with phytase as supplement on growth responses of rainbow trout. Turkish Journal of Agricultural-Food Science and Technology, vol. 8, no. 11, pp. 23552360. http://dx.doi.org/10.24925/turjaf.v8i11.2355-2360.3574.

SNEDECOR, G.W. and COCHRAN, W.G., 1991. Statistical methods. 8th ed. Americans, USA: Iowa State University Press, 503 p.

STEEL, R.G.D., TORRIE, J.H. and DICKEY, D.A., 1996. Principles and procedures of statistics. 3rd ed. New York: McGraw Hill International Book Co. Inc., pp. 336-352.

SUN, H., TANG, J.W., YAO, X.H., WU, Y.F., WANG, X., LIU, Y. and LOU, B., 2015. Partial substitution of fish meal with fermented cottonseed meal in juvenile black sea bream (Acanthopagrus schlegelii) diets. Aquaculture, vol. 446, pp. 30-36. http://dx.doi. org/10.1016/j.aquaculture.2015.04.020.

TAHOUN, A.M., ABO-STATE, H.A. and HAMMOUDA, Y.A., 2009 [viewed 20 January 2021]. Effect of adding commercial phytase to DDGS based diets on the performance and feed utilization of Nile tilapia (Oreochromis niloticus) fingerlings. American-Eurasian Journal of Agriculture and Environmental Science [online], vol. 5, pp. 550-555. Available from: http://www.idosi.org/.../15.pdf

WANG, F., YANG, Y.H., HAN, Z.Z., DONG, H.W., YANG, C.H. and ZOU, Z.Y., 2009. Effects of phytase pretreatment of soybean meal and phytase sprayed in diets on growth, apparent digestibility coefficient and nutrition excretion of rainbow trout (Oncorhynchus mykiss Walbaum). Aquaculture International, vol. 17, no. 2, pp. 143-157. http://dx.doi.org/10.1007/s10499008-9187-5.

YIN, X., LI, J., SHIN, H.-D., DU, G., LIU, L. and CHEN, J., 2015. Metabolic engineering in the biotechnological production of organic acids in the tricarboxylic acid cycle of microorganisms: advances and prospects. Biotechnology Advances, vol. 33, no. 6, pp. 830-841. http://dx.doi.org/10.1016/j.biotechadv.2015.04.006. PMid:25902192.

YUE, Y.R. and ZHOU, Q.C., 2008. Effect of replacing soybean meal with cottonseed meal on growth, feed utilization, and hematological indexes for juvenile hybrid tilapia, Oreochromis niloticus $\times$ O. aureus. Aquaculture, vol. 284, no. 1-4, pp. 185-189. http://dx.doi.org/10.1016/j.aquaculture.2008.07.030. 